\title{
Revisiting the relationship between farm mechanization and labour requirement in India
}

\author{
Pallavi Rajkhowa ${ }^{1}$ (D) $\cdot$ Zaneta Kubik $^{1}$
}

Accepted: 1 October 2021 / Published online: 18 October 2021

(C) The Author(s) 2021

\begin{abstract}
In many developing and emerging economies, better employment opportunities in the non-farm sector have increased rural wages due to labour shortages during the peak agricultural season. Increasing wages often cause a substitution of labour for mechanical power, but extensive use of labour-saving technologies may cause labour displacement and have serious equity concerns. Using the household and individual fixed effect estimation approach, this paper analyses the relationship between different types of farm machines and labour requirements in India. The results suggest that a unit increase in the level of farm mechanization increases the demand for hired labour by $12 \%$. Moreover, we find that the level of farm mechanization has a positive effect on women's participation in farm work, while it decreases the probability of children participating in agriculture-related work. Disaggregated analysis based on types of farm machinery suggests that water-lifting equipment, draft power and tractors increase the probability of male household members working on their farms, while all types of farm machines, except tractors, have a positive effect on female farm labour participation. We also find that the effect of farm mechanization on the demand for hired labour decreases as the size of the farm increases.
\end{abstract}

Keywords Farm mechanization · Agriculture · India

JEL Classification $\mathrm{J} 43 \cdot \mathrm{O} 33 \cdot \mathrm{Q} 12$

\section{Introduction}

In developing countries, increasing population densities, urbanization, and rising incomes have increased the need for sustainable agriculture intensification to meet the growing consumer food demand. Crop intensification is either possible through

Pallavi Rajkhowa

diptarajkhowa@gmail.com; pallavirajkhowa@uni-bonn.de

1 Center for Development Research (ZEF), University of Bonn, Genscherallee 3, 53113 Bonn, Germany 
the expansion of cultivable land or an increase in land productivity (Ruttan, 2002). Intensification of agricultural systems is usually associated with increased labour requirements per unit of cultivated area for land preparation, maintaining soil fertility, weeding, harvesting, processing, and maintaining draft animals (Binswanger \& Pingali, 1984). However, in many developing and emerging economies, increasing employment opportunities in the non-farm sector have increased rural wages due to labour shortages during the peak agricultural season (Wang et al., 2016). The theory of induced innovation suggests that increasing wages and labour scarcities cause a substitution of labour for mechanical power or labour-saving technologies (Binswanger \& Ruttan, 1978; Hayami \& Ruttan, 1970). However, extensive use of labour-saving technologies may cause labour displacement and have serious equity concerns (Malabo Montpellier Panel, 2018; Pingali, 2007). This concern is often raised concerning the mechanisation of farms in low-income countries and it needs to be assessed empirically (Daum \& Birner, 2020). Most of the earlier studies in the 1970 s and 1980s on farm mechanization were static assessments based on crosssectional data and they did not separate the effect of different types of mechanization (Benin, 2015; Mrema et al., 2008). However, the consequences of mechanization on employment can differ depending on the operation that is being mechanized and the level of agricultural productivity (Afridi et al., 2020). Mechanization can have a substitution effect by directly replacing labour in certain activities, or it could have a scale effect by increasing demand by improving overall productivity or expansion of cultivated land (Caunedo \& Kala, 2021). Using experimental evidence, Caunedo and Kala (2021) show the impact of subsidizing access to rental services on labour requirement, while Afridi et al. (2020), use an instrumental variable approach to analyse how the use of tractors and power tillers during the tilling stage of land preparation affects labour use by gender ${ }^{1}$ in the period 1999-2011. Furthermore, Caunedo and Kala (2021) estimate the intent to treat estimates where their main measure of mechanization identifies the impact of being given a farm machine rental subsidy voucher. They find that the rental subsidy programme declined female hired labour requirement as well as female and male family labour requirement on farm. Afridi et al. (2020) in their paper specifically analyse the effects of mechanization of the tilling phase of agriculture cultivation. They find that mechanization of tilling of land reduces overall female labour use on farm. This paper builds on this literature by using nationally representative panel data collected in 2004-2005 and 2011-2012. Here, we study the relationship between ownership of different types of farm machines - such as water-lifting equipment, draft power, tractors and threshers-and hired and family labour requirements applying household and individual fixed effect estimation approach. This paper also analyses the consequences of farm mechanisation on the expansion of farmland and intensification of input use to better understand the mechanisms of effect on farm labour requirement. Finally, the study examines the heterogeneous effects of farm mechanisation based on the size of cultivable land. During the period of the survey, rental services for farm machines

\footnotetext{
1 Afridi et al. (2020) analyse the overall impact on labour use diaggregated by gender but they do not distinguish between hired and family labour.
} 
were in their nascent phase in India and were available only in selected regions of the country. However, there was an expansion of ownership of farm machines due to the policies and programs introduced since 2000 which subsidized the purchase of farm equipment, and also the expansion of agricultural credit boosted the process of farm mechanization in India (Afridi et al., 2020). Thus, this paper studies the effects of ownership of different types of farm machines on labour requirements in Indian farms between 2004-2005 and 2011-2012. The novelty of this paper is that besides looking at the disaggregated effects on the implications of farm machines on family male labour, family female labour, and hired labour, it also analyses the effects on child labour and the heterogeneous effects of mechanization on labour requirement based on land size. Furthermore, we not only analyse the effects of mobile machinery such as tractors, but also stationary machineries such as electric and diesel pump sets and post-harvest machinery such as threshers. While mechanization, in general, is likely to have a differential effect on labour requirement-male vs female or family vs hired labour - so is the nature of the machine, the operation that is being mechanized and the level of farm mechanization. Thus, this paper aims to add to the existing literature on farm mechanization and its implications on labour market by analysing the effects of both mobile and stationary machines.

The paper proceeds as follows: Sect. 2 discusses the conceptual framework, while Sect. 3 describes the material and methods used in the paper. Section 4 presents the descriptive and the econometrics results while Sect. 5 concludes.

\section{Conceptual framework}

Theories on farm mechanization have highlighted that intensification of agriculture increases the demand for power for various agricultural operations such as land preparation, weeding, harvesting and threshing (Boserup, 1965; Pingali, 2007; Pingali et al., 1988). However, the transition of farm power from human power to animal or mechanical power only occurs when farmers perceive the shift as profitable, which in turn depends on economy specific factors such as land and labour endowment, non-agricultural demand for labour and demand for final agricultural products. The theory of induced innovation (Binswanger \& Ruttan, 1978; Hayami \& Ruttan, 1970; Ruttan \& Hayami, 1984) proposed that the direction of technical change in agriculture is induced by changes in relative resource endowments and factor prices. Based on historical experiences, the theory suggests that limitations on development due to an inelastic supply of labour may be compensated by a move towards mechanical technologies, while limitations imposed by an inelastic supply of land may be countered by biological technology (Pingali et al., 1988; Ruttan, 2002). Thus, for labour abundant and land constrained developing countries, such as India and China, the substitution of machine power for human power will occur when wages of labour rise substantially. However, this does not imply that for a land-scarce and low-wage country mechanization will not occur. Based on experience from Indian Punjab in the 1960s and 1970s, the literature on farm mechanization suggests that the shift of the source of power also depends on the level of power intensity and 
control intensity of the operation. It is well documented that in both land-scarce and land abundant countries, power-intensive operations such as land preparation, transport, milling, grinding and threshing usually mechanize before control-intensive operations such as weeding, sifting, winnowing and harvesting. While mechanization of power-intensive operations is closely associated with intensification of agriculture, control-intensive operations mechanize when there is a sharp increase in labour wages (Boserup, 1965; Pingali, 2007; Pingali et al., 1988). Thus, the mechanization of farms need not occur across all agriculture operations simultaneously but in a staggered manner depending on economic growth and the availability of off-farm opportunities. Therefore, the effect of farm mechanization on labour requirements may be positive or negative depending on the nature of the machine and the operation that is being mechanized. Pingali (2007) highlighted that the transition from draft power to mechanical power saves labour mainly during the land preparation phase of cultivation. However, when there is an expansion of cultivable land by bringing uncultivated land or fallow land under cultivation or by increasing cropping intensity, it is expected that demand for labour is shifted from land preparation to weeding and harvesting, which could lead to an overall increase in labour requirement. Furthermore, in developing countries, small-scale farmers often augment their farm labour requirement with family labour. Thus, the effect of farm mechanization may also vary with hired and family labour (Daum \& Birner, 2020). As the opportunity cost of family labour increases, it will be used more as a source of knowledge, management, and supervision, rather than as a source of power (Pingali, 1997). Consequently, mechanization may cause the substitution of hired labour for family labour. Keeping this theoretical background in mind, this paper revisits the relationship between different types of machines and labour requirements.

\section{Materials and method}

\subsection{Data}

The study uses the nationally representative Indian Human Development Survey (IHDS) (Desai et al., 2019) for the analysis. The IHDS data is a panel dataset collected in 2004-2005 and 2011-2012. In the first round, 41,554 randomly selected households in 1503 rural villages and 971 urban neighbourhoods across India were surveyed and in the second round, $83 \%(N=40,018)$ of the first-round households were re-interviewed and additional 2134 households were added, resulting in a total sample of 42,152 households in round-II. For the econometric analysis, the individual and household modules are used. The study uses the balanced subsample of cultivator households since data on farm machine ownership is available only for those households that cultivated any land. To create a balanced sample, we only use those cultivator households who allocated any land to crop cultivation in 2011-2012 $(N=26,478)$. 


\subsection{Measurement of variables}

\subsubsection{Farm mechanization}

The level of mechanization on the farm is measured by the total number of machines (tube wells, electric pump sets, diesel pump sets, bullock carts, tractors and threshers) a household owns. However, the total number of farm machines might not capture the quality of mechanization. For example, if we consider draft power and tractors as substitutes, and tractors being an upgrade compared to a draft animal, then the total number of machines might not reflect the quality aspect of mechanization. Thus, we use two additional measures as alternatives to capture the level of farm mechanization. First, we use principal component analysis to create an index of farm mechanization. The index is computed based on variables that measure the total number of tube wells, electric pump sets, diesel pump sets, bullock carts, tractors and threshers for each household. The first component is then used as the index for farm mechanization. Second, we use farm power availability in Kilowatt-hour as another measure of farm mechanization to capture the quality aspect of farm mechanization. We calculate the total power available on a farm by multiplying the number of farm machines by the power conversion factors, corresponding to different power sources, from Singh et al. (2014). ${ }^{2}$ Singh et al. (2014) provide conversion factors for draft animals, tractors, electric motors and diesel motors but not threshers. For that reason, the total power availability measure does not capture the latter. Therefore, in this paper, we use the total number of machines as the preferred measure of mechanization because of the simplicity of interpretation and because it captures all types of machines used in the farm including threshers. We, however, highlight that the IHDS dataset had information only on ownership of farm machinery and not farm rental services and, therefore, our measure of farm mechanization does not include farm rental services, which is currently a common practice in India. However, during the period of the survey, rental services for farm machines were in their nascent phase and only in selected regions of the country, but there was an expansion of ownership of farm machines due to the policies and programs which subsidized the purchase of farm equipment (Afridi et al., 2020). Thus, we do not expect our results to be strongly affected by this omission.

Furthermore, to understand the implications of different types of machines on labour requirement we use the following binary variables:

i. Water lifting equipment: takes the value of 1 if the household owns at least one tube well, electric or diesel pump set;

ii. Draft power: takes the value of 1 if the household owns at least one bullock cart;

iii. Tractor: takes the value of 1 if the household owns at least 1 tractor;

iv. Thresher: takes the value of 1 if the household owns at least one thresher.

\footnotetext{
${ }^{2}$ Farm power conversion rates: 1 draft animal $=0.38 \mathrm{~kW} ; 1$ tractor $=26.1 \mathrm{~kW} ; 1$ electric motor $=3.7 \mathrm{~kW}$; 1 diesel motor $=5.6 \mathrm{~kW}$.
} 


\subsubsection{Demand for farm labour}

Demand for farm labour is measured in terms of (i) hired labour and (ii) household labour. Hired labour is measured in terms of labour intensity used per unit of cultivated land in a year (mandays per unit of cultivated land). The IHDS collected information on the total mandays of labour hired for farming in the last 12 months. We use this information to calculate labour intensity by dividing the total mandays by the total cultivated area for that year. For our main specification, we use the log transformation of labour intensity as the main dependent variable, but we also present in the Online Appendix the estimates with inverse hyperbolic transformation of the dependent variable to account for zeros as robustness check.

Furthermore, the IHDS dataset also has information on each household members' involvement in farming and off-farm activities. Therefore, we measure household labour demand by three dichotomous variables: (1) adult male member participates in farm labour; (2) adult female member participates in farm labour, and (3) child participates in farm labour.

\subsection{Estimation strategy}

\subsubsection{Average effects}

To analyse the relationship between farm mechanization and demand for hired labour, the following household fixed effect regressions are estimated:

$$
Y_{i t}=\alpha_{o}+\alpha_{1} M_{i t}+\alpha_{2} X_{i t}+\alpha_{3} T_{t}+w_{i}+\varepsilon_{i t},
$$

where $Y_{i t}$ is the outcome variable of interest indicating hired labour by household $i$ in year t. $M_{i t}$ refers to farm mechanization, our main explanatory variable. As explained in Sect. 3.2, $M_{i t}$ is used either as a continuous variable, representing the level of farm mechanization, or as a binary variable taking a value of 1 if the household owns a specific type of farm machinery. $X_{i t}$ is a vector of household characteristics that may also influence the outcome variable, $T_{t}$ is a year dummy variable to control for time fixed effects, $w_{i}$ is the household fixed effect, and $\varepsilon_{i t}$ is a random error term. The errors $\varepsilon_{i t}$ are robust and clustered at the village level to account for possible heteroscedasticity and serial correlation within villages. We use the fixed effect (FE) estimator rather than the random effects estimator since households self-select into machine ownership based on observed and unobserved characteristics, which is likely to result in a correlation between the farm mechanization variable and the error term. This, in turn, could lead to biased estimates of the coefficient of interest. Under these circumstances, the fixed effects estimator is more suitable because it controls for time-invariant unobserved heterogeneity (Cameron \& Trivedi, 2005). ${ }^{3}$

\footnotetext{
3 An alternative method to address the selection bias would be to apply the Heckman-type selection models. This would, however, require a valid exclusion restriction, for which the theory underlying our econometric specification does not suggest any suitable candidate. In addition, such models would only address the selection based on observable factors.
} 
Furthermore, to estimate the relationship between ownership of farm equipment and individual household member's decision to participation in farm labour, we use an individual fixed effect linear probability model (FE-LPM). As mentioned earlier, the IHDS dataset has information about each household members' decision to participate in their own farm. We combine this information with the household level information about ownership of farm equipment and estimate the following model:

$$
H_{j i t}=\beta_{o}+\beta_{1} M_{i t}+\beta_{2} I_{j i t}+\beta_{3} X_{i t}+\beta_{4} T_{t}+\theta_{j i}+\mu_{j i t},
$$

where $H_{j i t}$ is a binary variable taking the value of 1 if a member $j$ from household $i$ participates in their farm, and 0 otherwise. $I_{j i t}$ is a vector of variables representing individual characteristics, $\theta_{j i}$ is the individual fixed effect and $u_{j i t}$ is a random error term. The other variables are defined as above. The errors are robust and clustered at the household level to account for possible heteroscedasticity and serial correlation within households. The study estimates Eq. (2) separately for sub-samples of men, women and children to understand the disaggregated effects of farm mechanization on household participation in farm labour.

Additionally, to better understand the underlying mechanism, the study also estimates the effect of farm mechanisation on the expansion of cultivated land and the intensity of input use per unit of cultivable area. It is expected that farm mechanisation will have a positive effect on the demand for labour if mechanisation leads to the expansion of cultivable land and the intensity of input use. Finally, it is also expected that, along with labour demand, the adoption of farm mechanization also affects labour productivity (Hayami \& Ruttan, 1970). However, due to data limitations, we are not able to estimate such effects in this paper.

\subsubsection{Heterogeneous effects}

The relationship between farm mechanization and labour requirements may differ based on the size of cultivable land. It is expected that small farms may initially mechanize only the most labour intensive operation such as water-lifting or land preparation, which might reduce labour requirement in these operations but may increase labour requirement in other operations such as application of inputs or postharvest activities due to increased expansion of cultivable land or cropping intensification. Large farms, however, may have the capacity to own several types of machines that can reduce labour requirements across several activities. We test this hypothesis of heterogeneous effect on demand for labour with household fixed-effect models of the following type:

$$
Y_{i t}=\alpha_{o}+\alpha_{1} M_{i t}+\alpha_{2} X_{i t}+\alpha_{3} Z_{i t}+\alpha_{4} M_{i t} \times Z_{i t}+\alpha_{5} T_{t}+w_{i}+\varepsilon_{i t},
$$

where $Z_{i t}$ measures the size of owned land. The other variables are described above. In this specification, we are not only interested in the estimated coefficient $\alpha_{1}$ but also on the coefficient $\alpha_{4}$ for the interaction term between farm mechanization or the type of farm machinery and the size of land. A negative and significant estimate for $\alpha_{4}$ will confirm the hypothesis that as the size of land increases, the effect of farm machinery on demand for labour reduces. 
Furthermore, we also analyse the heterogeneous effects on family farm labour with individual linear probability fixed-effect models of the following type:

$$
H_{j i t}=\beta_{o}+\beta_{1} M_{i t}+\beta_{2} I_{j i t}+\beta_{3} X_{i t}+\beta_{4} Z_{i t}+\beta_{5} M_{i t} \times Z_{i t}+\beta_{6} T_{t}+\theta_{j i}+\mu_{j i t},
$$

where the explained and explanatory variables are specified as above.

\section{Results and discussion}

\subsection{Descriptive statistics}

Table 1 shows the pattern of ownership of farm machines in India in 2012 using the IHDS data (round II). On average, around $40 \%$ of households owned at least one farm machine, while the remaining $60 \%$ did not own a single machine. Disaggregating the data by cultivated land quartiles shows that ownership of farm machines increased with farm size. However, even amongst the largest farmers, around $55 \%$ of households did not own any farm machines. Further, farm power availability remained low, ranging between 1 and 5 Kilowatt amongst the smallest and largest landholdings, respectively. Additionally, Fig. 1 presents data on the ownership of different types of farm machines between 2004-2005 and 2011-2012 disaggregating by marginal and small ( $<5$ acres of land), medium (5-10 acres of land) and large farms ( $>10$ acres of land). As one would expect, the figure highlights that medium and large-sized farms are relatively more mechanized compared to marginal and small farms. In 2011-2012, around $40 \%$ of medium and large farms owned water-lifting equipment, 7-13\% owned a tractor, 5-6\% owned threshers and 13-19\% owned bullock carts. In comparison, $27 \%$ of marginal and small farms owned irrigation machines, $2 \%$ owned tractors and threshers and $10 \%$ owned bullock carts. Furthermore, between 2004-2005 and 2011-2012, ownership of bullock carts decreased across all farm types, while possession of water-lifting equipment such as tube wells, electric and diesel pump sets and tractors increased for marginal, small and medium-sized farms. Thus, indicating a shift from draft animal power to mechanical power for farm operations across farm sizes. Amongst large-sized farms, ownership of machines such as irrigation equipment, tractors and threshers marginally declined, which could be due to the depreciation of farm machines.

Furthermore, in Fig. 2, we present the share of farm power from different sources disaggregated by farm size. For this, we use the data from IHDS on the number of farm equipment and use the conversion factors given in Singh et al. (2014) to get the total farm power in Kilowatts from different sources. Figure 2 shows that, in India, the electric motor is the main source of farm power (40\%) across all farm types. However, between 2004-2005 and 2011-2012, the share of diesel power in total available farm power has increased amongst marginal and small farms, while it has decreased for large farms. Furthermore, to meet the increased demand for mobile power, the share of tractor power in total farm power has increased not only for medium and large farms but also for marginal and small farms, while the use of draft animal power has declined for all farm types. 


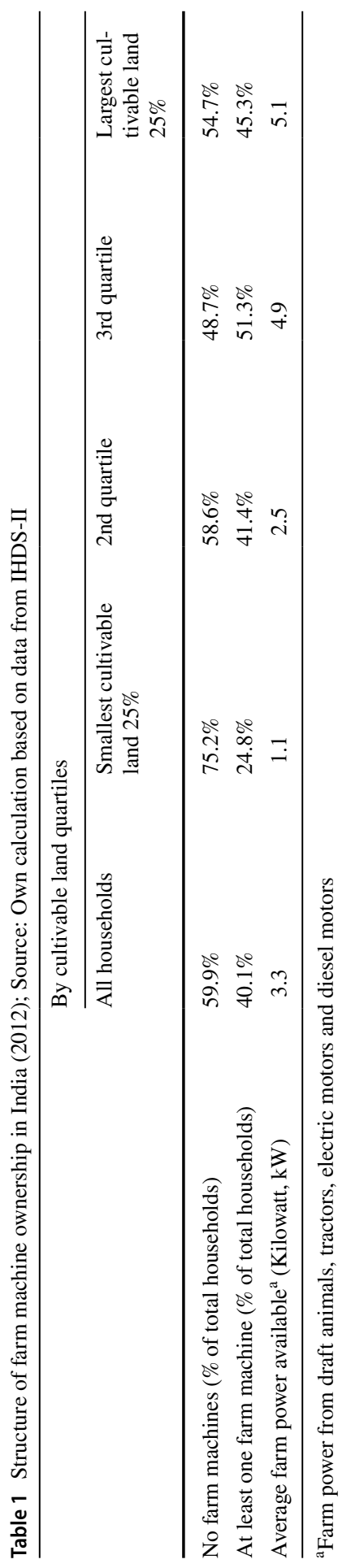




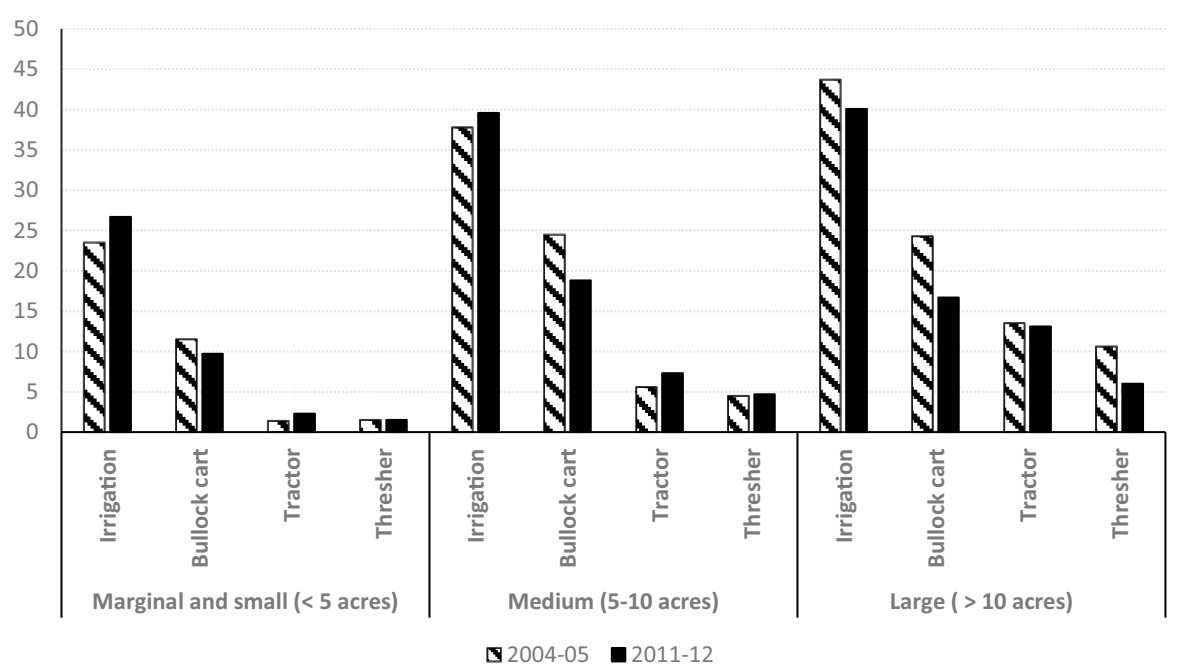

Note: Farmer categorization based on cultivable land (in acres)

Source: Own presentation based on data from IHDS-I and IHDS-II.

Fig. 1 Farm mechanization between 2004-2005 and 2011-2012 in India. Note: Farmer categorization based on cultivable land (in acres). Source: Own presentation based on data from IHDS-I and IHDS-II

In Table 2, we present the summary statistics of the variables used in the econometric analysis for the pooled sample and in Table A1 in the Online Appendix, we show the data disaggregated by year. Data suggest that on average, 33\% of the sample of cultivator households owned water-lifting equipment, $16 \%$ possessed draft animals, $7 \%$ owned a tractor and $4 \%$ had threshers. Households in our sample had on average about 24 acres of cultivated land, with substantial variation across the sample. Disaggregating the data by cultivated land quartiles show that the lowest quartile had on average about one acre of cultivated land, while the second and third quartile cultivated about 4 and 9 acres, respectively. Households in the largest cultivated land quartile on average cultivated about 86 acres of land with large within-group variation as represented by the standard deviation. Furthermore, data on expenditure on inputs and quantum of labour hired suggest that households on average spent about 1849 rupees worth of inputs per unit of cultivated land and used around 8 mandays of hired labour per unit of cultivated land. Here too, we observe substantial variation across the sample as well as economies of scale. In general, households with large cultivable land used less hired labour and spent less on inputs per acre of cultivated land compared to households with a smaller size of cultivable land (see Table 2).

In terms of household characteristics, around $85 \%$ of the households were headed by a male member, aged around 51 years and with 5 years of education on average. Furthermore, $70 \%$ of cultivator households were involved in off-farm employment and $20 \%$ of them were BPL (below the poverty line) households. 


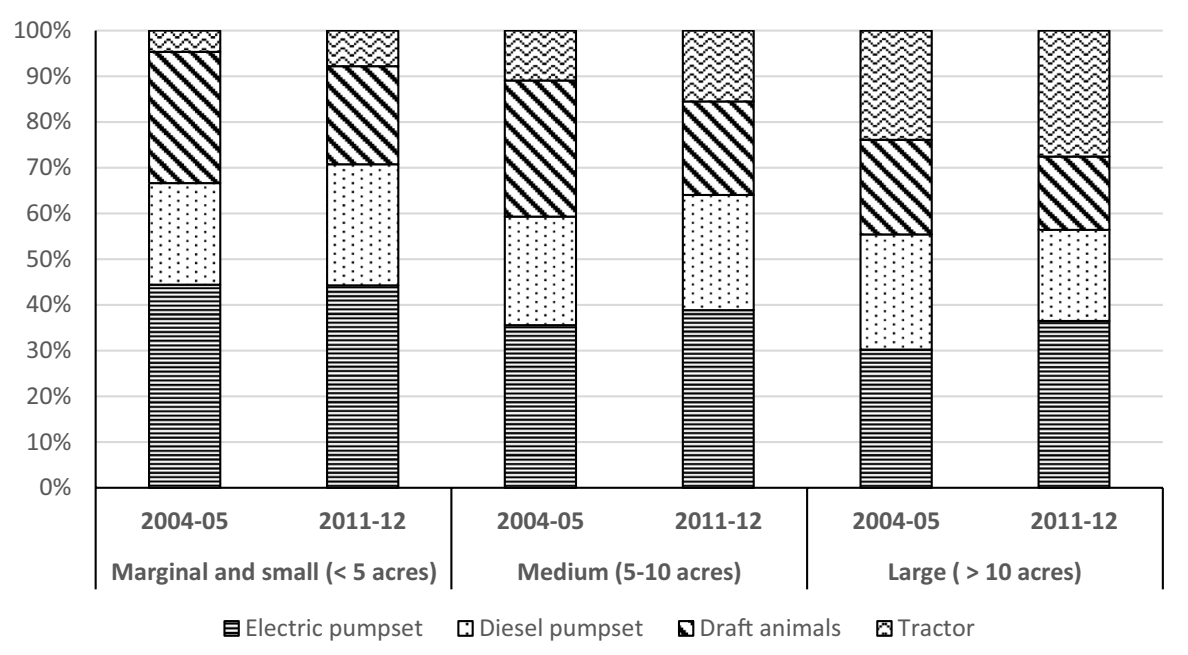

Note: Farmer categorization based on cultivable land (in acres)

Source: Own presentation based on data from IHDS-I and IHDS-II.

Fig. 2 Farm power from different sources. Note: Farmer categorization based on cultivable land (in acres). Source: Own presentation based on data from IHDS-I and IHDS-II

\subsection{Average effects}

\subsubsection{Relationship between farm mechanization and hired labour requirement}

Table 3 shows the regression results of the fixed effect model explained in Eq. (1). The level of farm mechanization has a statistically significant positive effect on the demand for hired labour. The estimates in column (1) suggest that an increase in the number of farm machines by one unit increases the demand for hired labour by $12 \%$. Furthermore, to understand the mechanism through which farm mechanization affects hired labour requirement, we present in columns (2) and column (3) the fixed effect results with cultivated land and input use intensity as outcome variables. From these two columns, it can be inferred that the level of farm mechanisation has a positive and significant relationship with expansion of cultivable land and the intensity of inputs used such as seeds, fertilizers and pesticides. All else equal, a unit increase in the number of farm machines is associated with an increase in cultivable land by $8 \%$ and input expenditure per acre by $11 \%$. These results indicate that with increased farm mechanisation, the demand for labour need not decrease but it can increase due to the increased need for labour for land preparation, input application due to increased cropping intensity and post-harvest activities. A general concern regarding using log-transformed variables is that it is not defined for variables that take a value of zero. In line with the usual practice, we address this issue by adding a small positive number to all the dependent variables before the log-transformation. As a robustness check, we also show the results using the inverse hyperbolic sine transformation of all the dependent variables in Table A2 in the Online Appendix. These results are very similar to the ones presented in Table 3 . Furthermore, since 
Table 2 Summary statistics

\begin{tabular}{|c|c|c|}
\hline & \multicolumn{2}{|c|}{ Pooled sample } \\
\hline & Mean & Standard deviation \\
\hline Number of farm machines & 0.812 & 1.328 \\
\hline Water-lifting equipment (dummy) & 0.334 & 0.472 \\
\hline Draft animal (dummy) & 0.161 & 0.368 \\
\hline Tractor (dummy) & 0.065 & 0.247 \\
\hline Thresher (dummy) & 0.043 & 0.204 \\
\hline Male head (dummy) & 0.855 & 0.352 \\
\hline Age of head (years) & 51.236 & 13.030 \\
\hline Education of head (years) & 4.977 & 4.544 \\
\hline Household size (number) & 5.991 & 3.031 \\
\hline Dependent (number) & 2.476 & 1.976 \\
\hline Owned land (acres) & 25.123 & 179.033 \\
\hline Off farm employment (dummy) & 0.699 & 0.459 \\
\hline Poor (dummy) & 0.200 & 0.400 \\
\hline Credit (dummy) & 0.577 & 0.494 \\
\hline Household assets (index) & 8.925 & 3.449 \\
\hline Livestock (number) & 1.294 & 1.353 \\
\hline Rooms (number) & 2.985 & 1.927 \\
\hline Urban (dummy) & 0.036 & 0.185 \\
\hline Hired labour (log) & 0.204 & 2.069 \\
\hline Cultivated land (log) & 1.820 & 1.425 \\
\hline Input intensity (log) & 6.514 & 1.792 \\
\hline Hired labour (mandays per acre) & 7.863 & 67.791 \\
\hline \multicolumn{3}{|l|}{ By cultivable land quartiles } \\
\hline Smallest cultivable land $25 \%$ & 14.203 & 129.050 \\
\hline 2nd quartile & 7.557 & 15.675 \\
\hline 3rd quartile & 6.611 & 21.106 \\
\hline Largest cultivable land $25 \%$ & 2.532 & 7.956 \\
\hline Cultivated land (acres) & 24.242 & 125.460 \\
\hline \multicolumn{3}{|l|}{ By cultivable land quartiles } \\
\hline Smallest cultivable land $25 \%$ & 1.422 & 0.543 \\
\hline 2nd quartile & 3.785 & 0.8865 \\
\hline 3rd quartile & 8.540 & 2.121 \\
\hline Largest cultivable land $25 \%$ & 85.586 & 243.369 \\
\hline Input intensity (Rupees per acre) & 1849.134 & 2801.606 \\
\hline \multicolumn{3}{|l|}{ By cultivable land quartiles } \\
\hline Smallest cultivable land $25 \%$ & 2683.53 & 3653.470 \\
\hline 2nd quartile & 2074.91 & 2570.140 \\
\hline 3rd quartile & 1795.09 & 2424.230 \\
\hline Largest cultivable land $25 \%$ & 750.924 & 1764.840 \\
\hline Observations & 26,478 & \\
\hline
\end{tabular}


Table 3 Association between farm mechanization and demand for hired labour, cultivable land and input use intensity (household fixed effects)

\begin{tabular}{|c|c|c|c|c|c|c|}
\hline & \multicolumn{2}{|l|}{ (1) } & \multicolumn{2}{|l|}{ (2) } & \multicolumn{2}{|l|}{ (3) } \\
\hline & \multicolumn{2}{|c|}{ Hired labour (log) } & \multicolumn{2}{|c|}{ Cultivated land (log) } & \multicolumn{2}{|c|}{ Input intensity (log) } \\
\hline & Coefficient & SE & Coefficient & SE & Coefficient & SE \\
\hline Farm machines (number) & $0.117 * * *$ & $(0.028)$ & $0.081 * * *$ & $(0.013)$ & $0.112 * * *$ & $(0.017)$ \\
\hline Male head (dummy) & $-0.325^{* *}$ & $(0.130)$ & $0.220 * * *$ & $(0.066)$ & $-0.168 * *$ & $(0.072)$ \\
\hline Age of head (years) & -0.002 & $(0.004)$ & $0.004 * *$ & $(0.002)$ & -0.002 & $(0.002)$ \\
\hline Education of head (years) & -0.000 & $(0.009)$ & $-0.015^{* * *}$ & $(0.005)$ & 0.003 & $(0.006)$ \\
\hline Household size (number) & $-0.088 * * *$ & $(0.016)$ & $0.050 * * *$ & $(0.009)$ & $0.021^{*}$ & $(0.012)$ \\
\hline Dependents (number) & $0.055^{* * *}$ & $(0.018)$ & 0.000 & $(0.010)$ & $-0.037 * * *$ & $(0.013)$ \\
\hline Owned land (acres) & $-0.002 *$ & $(0.001)$ & $0.002 * *$ & $(0.001)$ & $-0.002 * *$ & $(0.001)$ \\
\hline Off farm employment(dummy) & $-0.289 * * *$ & $(0.063)$ & -0.017 & $(0.037)$ & $-0.259 * * *$ & $(0.045)$ \\
\hline Poor (dummy) & -0.083 & $(0.073)$ & -0.057 & $(0.042)$ & $-0.151 * * *$ & $(0.050)$ \\
\hline Credit (dummy) & $-0.130 * *$ & $(0.052)$ & $0.142 * * *$ & $(0.031)$ & $-0.136^{* * *}$ & $(0.040)$ \\
\hline Household assets (index) & $0.046^{* * *}$ & $(0.014)$ & $0.036^{* * * *}$ & $(0.008)$ & 0.006 & $(0.010)$ \\
\hline Livestock (number) & -0.033 & $(0.021)$ & $0.060 * * *$ & $(0.012)$ & 0.018 & $(0.015)$ \\
\hline Rooms (number) & $0.046^{* * *}$ & $(0.017)$ & -0.005 & $(0.010)$ & 0.015 & $(0.012)$ \\
\hline Urban (dummy) & -0.122 & $(0.261)$ & $0.356^{*}$ & $(0.197)$ & -0.115 & $(0.301)$ \\
\hline Year 2012 (dummy) & $-0.458 * * *$ & $(0.058)$ & 0.051 & $(0.036)$ & $0.101 * *$ & $(0.042)$ \\
\hline Constant & $0.941 * * *$ & $(0.284)$ & $0.588 * * *$ & $(0.155)$ & $6.796 * * *$ & $(0.175)$ \\
\hline Observations & 23,135 & & 26,073 & & 26,073 & \\
\hline
\end{tabular}

Notes: Standard errors are robust and cluster-corrected at the village level. ${ }^{*}$ Significant at $10 \%$ level. **Significant at 5\% level. ***Significant at $1 \%$ level. Hired labour is measured in terms of mandays per unit of cultivated land (mandays per acre). Input intensity is measured in terms of expenditure on seeds, fertilizers and pesticides in rupees per acre. The dependent variable hired labour was transformed by adding a small positive number to the original variable and then it was log transformed. We also show the results using the inverse hyperbolic sine transformation of all the dependent variables in Table A2 in the Online Appendix

the continuous measure of mechanization is highly skewed towards zero, we also present the results with the log-transformed specification of farm mechanization in Table A3 and inverse hyperbolic sine transformed variables in Table A4 in the Online Appendix. In addition, we present the results with PCA-based farm mechanization index and total farm power availability as alternative measures of farm mechanization in Tables A5 and A6, respectively, in the Online Appendix. The findings of these robustness checks are similar to the results in Table 3, albeit the magnitudes are smaller.

In Table 4, we present the regression results of the effects of different types of farm machines on hired labour requirements. Column (1) and column (2) show that water-lifting equipment such as tube wells, electric motors and diesel pump sets and draft power such as bullock carts have a positive and significant relationship with demand for hired labour. The estimates indicate that ownership of irrigation machines and draft power increases the demand for hired labour by $24 \%$ and $19 \%$, respectively. However, we do not find a significant effect of tractors and threshers 


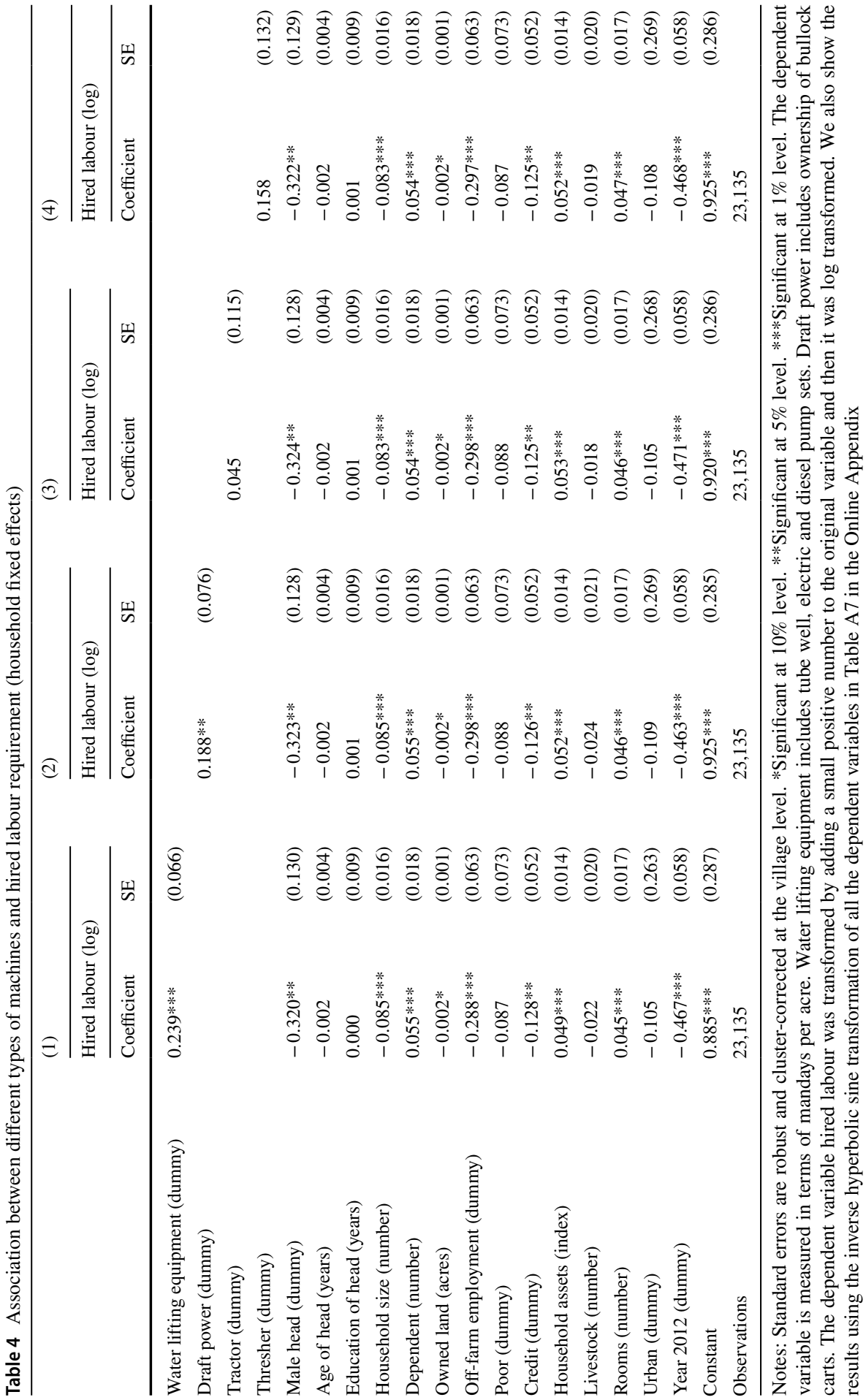


on-demand for hired labour. This could be because not many households own tractors and threshers; furthermore, very few cultivators registered a positive transition in ownership between the two rounds.

To have some understanding of the mechanism through which these farm machines affect hired labour demand, we present in Tables 5 and 6, the regression results on the effects of different types of farm machines on cultivated land and input use intensity, respectively. Table 5 suggests that all types of machines have a positive and significant effect on the expansion of cultivable land. The effect, however, is largest for those who own tractors (30\%), and threshers (24\%). Furthermore, Table 6 suggests that only water-lifting equipment and draft power have a positive and significant effect on input use intensity. These results indicate that water-lifting equipment and draft power raises the demand for hired labour through increased labour requirement for land preparation of expanded cultivable land, input application and post-harvest activities. Furthermore, column (3) in Table 4 shows a positive association between ownership of tractors and the demand for hired labour, however, we do not find a statistically significant effect. Tractors might reduce the need for hired labour for land preparation but it can increase the demand for labour for other postharvest activities. Similarly, threshers might reduce the demand for hired labour for post-harvest activities such as threshing, but it can increase the demand for hired labour for other farming activities. Furthermore, we also observe a positive association between ownership of threshers and demand for hired labour (Table 4 column (4)), the effect, however, is not significant.

\subsubsection{Relationship between farm mechanization and household labour participation}

In this section, we discuss the relationship between ownership of farm machines and household labour participation disaggregated by male and female adult labour and child labour. In Table 7 the LPM individual fixed effect results as explained in Eq. (2) is presented. We find that the level of farm mechanization does not have a statistically significant effect on men's probability of working on the farm. As before, to account for zeros in the continuous measure of mechanization, we also present the results with the log-transformed specification of farm mechanization in Table A12 and inverse hyperbolic sine transformed variables in Table A13 in the Online Appendix as a robustness check. These estimates are more aligned with expectation, and we find a significant positive relationship between the level of farm mechanization and men's probability of working on their own farm. Furthermore, we also find that farm mechanization has a statistically significant and positive effect on women's probability of working on the farm, while it decreases the probability of children participating in farm-related work. However, the effect is small in magnitude. The estimates in columns (2) and column (3) in Table 7 suggest that a unit increase in the ownership of farm machines increases the probability of adult female household members working on their farm by 0.6 percentage points while it decreases the probability of child labour by 1 percentage point. The latter has particularly important implications in that not only mechanization has a direct negative impact on child labour, but in addition, once we account for 


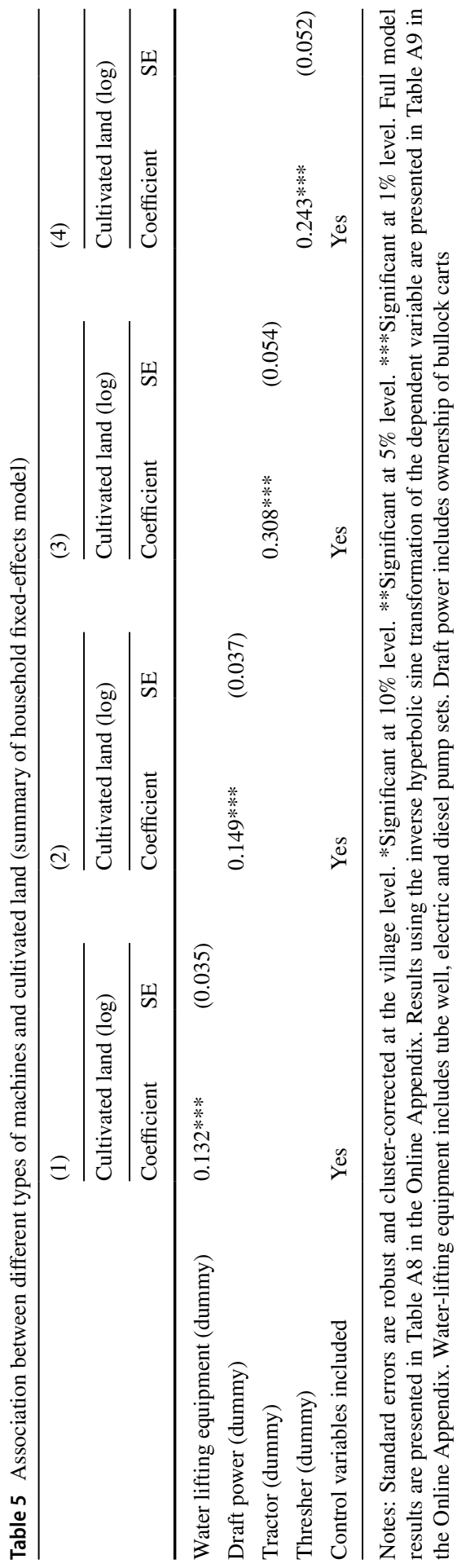




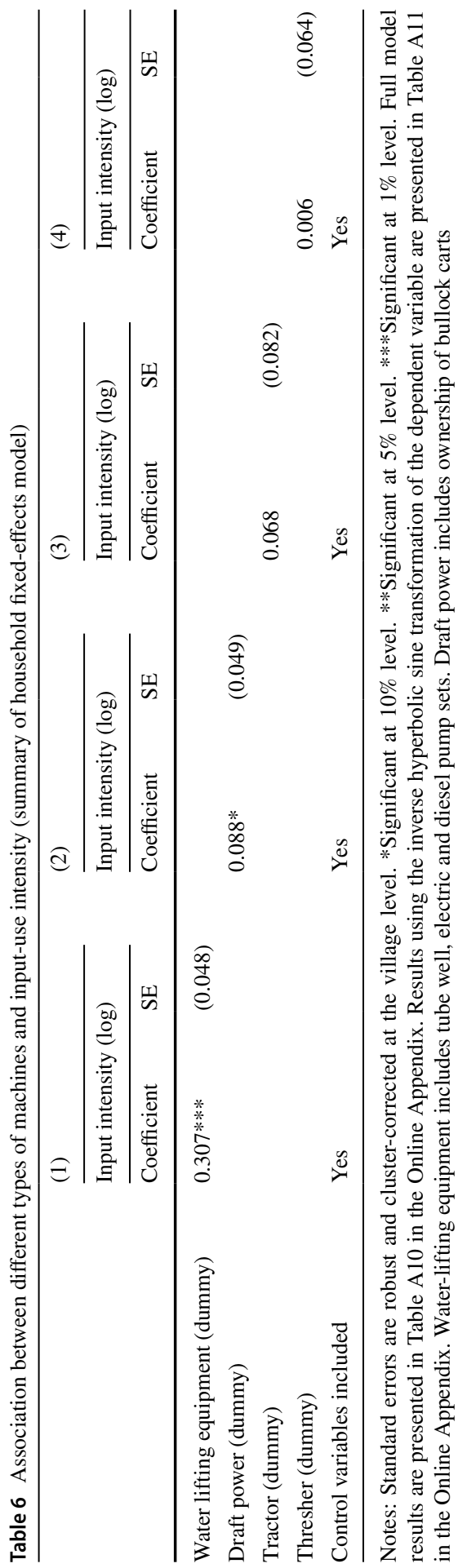


Table 7 Association between farm mechanization and household labour (LPM individual fixed effects)

\begin{tabular}{|c|c|c|c|c|c|c|}
\hline & \multicolumn{2}{|l|}{ (1) } & \multicolumn{2}{|l|}{ (2) } & \multicolumn{2}{|l|}{ (3) } \\
\hline & \multicolumn{2}{|l|}{ Adult male } & \multicolumn{2}{|l|}{ Adult female } & \multicolumn{2}{|l|}{ Children } \\
\hline & \multicolumn{2}{|c|}{$\begin{array}{l}\text { work on the farm } \\
\text { (dummy) }\end{array}$} & \multicolumn{2}{|c|}{$\begin{array}{l}\text { work on the farm } \\
\text { (dummy) }\end{array}$} & \multicolumn{2}{|c|}{$\begin{array}{l}\text { work on the farm } \\
\text { (dummy) }\end{array}$} \\
\hline & Coefficient & SE & Coefficient & SE & Coefficient & SE \\
\hline Farm machines (number) & 0.003 & $(0.003)$ & $0.006^{*}$ & $(0.004)$ & $-0.009 * * *$ & $(0.003)$ \\
\hline Age (years) & $-0.004 * * *$ & $(0.001)$ & $-0.006^{* * *}$ & $(0.001)$ & $-0.017 * * *$ & $(0.003)$ \\
\hline Married (dummy) & $0.135^{* * * *}$ & $(0.011)$ & $0.052 * * *$ & $(0.014)$ & & \\
\hline Attended school (dummy) & $0.022 * *$ & $(0.010)$ & -0.007 & $(0.014)$ & & \\
\hline Education (years) & & & & & $0.024 * * *$ & $(0.002)$ \\
\hline Household size (number) & $-0.012 * * *$ & $(0.001)$ & $-0.016^{* * *}$ & $(0.002)$ & & \\
\hline Dependent ratio & & & & & $-0.169 * * *$ & $(0.025)$ \\
\hline Off farm employment ${ }^{\mathrm{a}}$ (dummy) & -0.004 & $(0.007)$ & 0.007 & $(0.008)$ & $-0.018^{*}$ & $(0.010)$ \\
\hline Owned land (acres) & 0.000 & $(0.000)$ & $0.000 * * *$ & $(0.000)$ & $0.000 * *$ & $(0.000)$ \\
\hline Hired labour $(\log )$ & 0.002 & $(0.002)$ & -0.003 & $(0.002)$ & $-0.006^{* * *}$ & $(0.002)$ \\
\hline Livestock (number) & $0.006^{* *}$ & $(0.002)$ & 0.001 & $(0.003)$ & 0.004 & $(0.003)$ \\
\hline Credit (dummy) & $0.026 * * *$ & $(0.006)$ & $0.046 * * *$ & $(0.007)$ & 0.013 & $(0.008)$ \\
\hline Social group membership (index) & -0.022 & $(0.025)$ & $-0.072 * *$ & $(0.030)$ & 0.001 & $(0.032)$ \\
\hline Year 2012 (dummy) & $0.056 * * *$ & $(0.009)$ & $0.084 * * *$ & $(0.010)$ & $0.253 * * *$ & $(0.022)$ \\
\hline Constant & $0.865^{* * *}$ & $(0.040)$ & $0.877 * * *$ & $(0.047)$ & $0.204 * * *$ & $(0.025)$ \\
\hline Observations & 41,387 & & 37,701 & & 31,039 & \\
\hline
\end{tabular}

Notes: Standard errors are robust and cluster-corrected at the household level. *Significant at $10 \%$ level. $* *$ Significant at $5 \%$ level. ***Significant at $1 \%$ level. The dependent variable is a dichotomous variable indicating whether a household member worked on their farm. Children are defined as individual who are less than 15 years of age. ${ }^{a}$ Main source of income. Table A12 in the Online Appendix presents the results with log-transformed farm mechanization as the main explanatory variable and Table A13 presents the results with inverse hyperbolic sine transformation of the farm mechanization variable. Table A14 and Table A15 in the Online Appendix presents the results with PCA based farm mechanization index and farm power availability, respectively, as the main explanatory variable of interest

mechanization, child labour might also be replaced by hired labour, further reinforcing the direct impact of mechanization.

Furthermore, to understand the relationship between different types of farm machines and household labour requirements, the disaggregated analysis is presented in Tables 8, 9 and 10. Table 8 suggests that water-lifting equipment, draft power and tractors increase the probability of adult male members working in their farms. Amongst the three types of machines, tractor ownership has the largest effect on the likelihood of male household labour participation on their farm (4 percentage points). These results hint that the type of farm activities that male member is involved in might change after mechanization. For example, in Table 8, the coefficient of hired labour (column (2-4)), suggests that as the number of hired labour increases the probability of male members involved in farm 


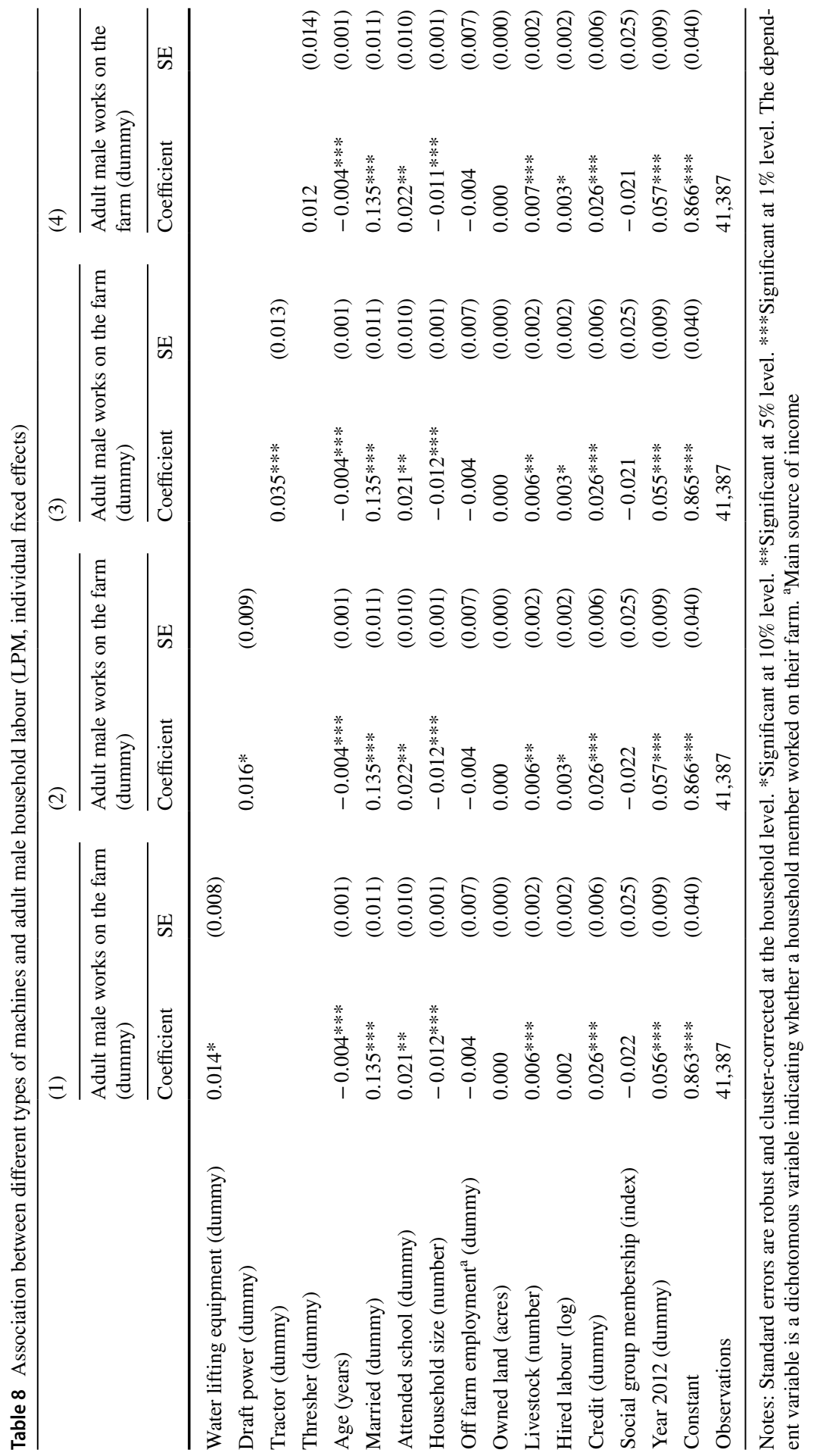




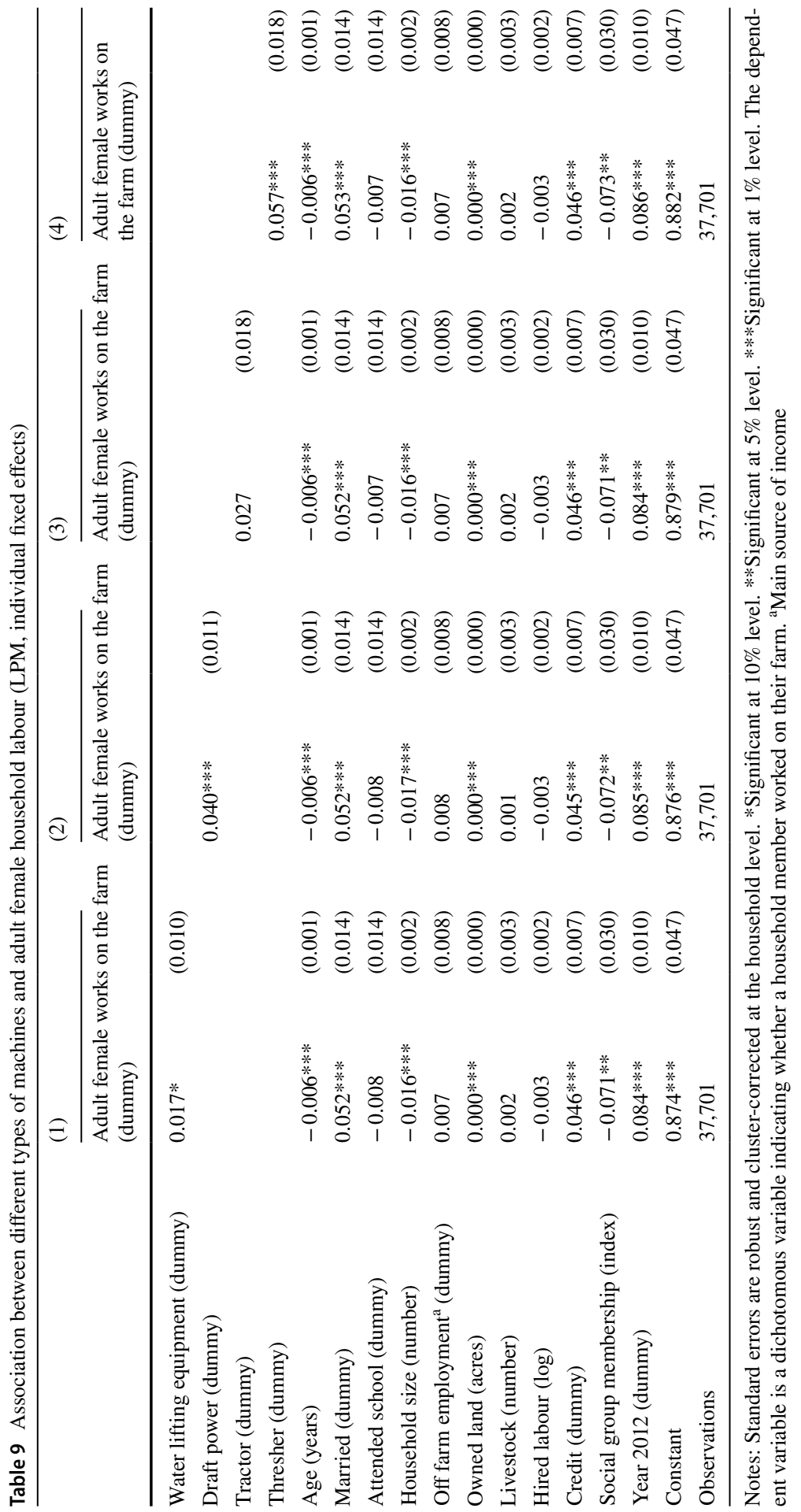




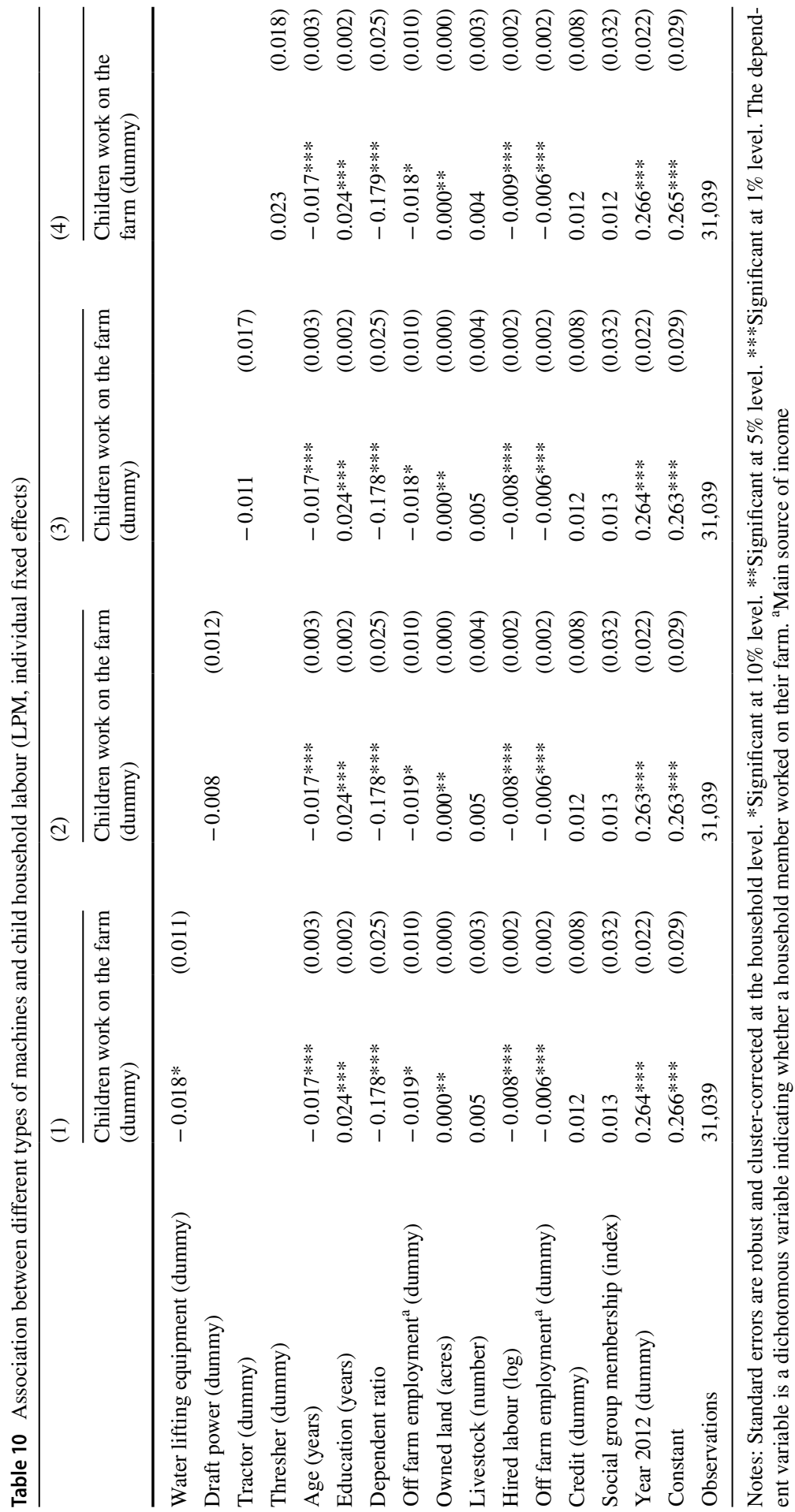


labour increases. This could be because males need to increase supervision or control of hired workers, especially if their number increases after mechanization.

Table 9 presents the results of the effects of farm mechanization on women's labour participation on their farms. We find that all types of farm machines, except tractors, have a positive effect on the likelihood of female farm labour participation. Moreover, threshers have the largest effect on the probability of women's participation in their farm, increasing it by 6 percentage points (column (4) in Table 9). In Table 10, we present the effects of different types of farm machinery on the probability of a child working on the farm. We find that only water-lifting equipment has a statistically significant effect on child labour. The estimates in column (1) suggest that the use of irrigation, but not other types of machinery, reduces the probability of child labour by around 2 percentage points. Additionally, column (4) in Table 10 suggests that although the results are not significant, there is a positive association between ownership of threshers and child labour. The disaggregated results in Tables 8, 9 and 10 suggest that the effect of farm machines on household labour differ by the type of farm machinery. Some machines are mainly used by male members such as tractors, and this translates into a higher probability of male member participation on farms, while machines such as threshers have a larger effect on women's participation in farm labour. Furthermore, water-lifting equipment has an important implication on the reduction of child labour participation on the farm.

\subsection{Heterogeneous effects}

In this section, we analyse whether the effects of farm mechanization on hired labour and household labour differs by farm size, as explained in Sect. 3.3.2. Table 11 presents the regression results of Eq. (3), which controls for the size of land, but also includes the interaction term between land size and respective mechanization indicator to better understand the heterogeneous impacts of mechanization on the demand for hired labour. In column (1) of Table 11, we interact the level of farm mechanization as measured by the number of farm machines with the size of owned land. Column (2) to column (5) analyses the heterogeneous effect of different types of machines on the demand for hired labour. In column (1) to column (5), the interaction term is significant and negative, implying that the effect of farm machines on the demand for hired labour decreases with farm size. In other words, as the size of owned land increases, irrespective of the type of farm machine, the demand for hired labour decreases. Furthermore, compared to Tables 4 and 11 shows that once we account for the heterogeneity in the effect of farm mechanization on demand for labour demand by farm size, the effects of different farm machines are also much larger. It is likely that due to limited access to capital, smaller farms initially mechanize only the most labour intensive operation such as water-lifting and land preparations, which could reduce labour requirements in these operations. However, increased expansion of cultivable land or cropping intensification might increase labour requirement in other operations such as the application of inputs or post-harvest activities. In contrast, larger farms usually can own several types of machines that can reduce labour requirements across several activities. 


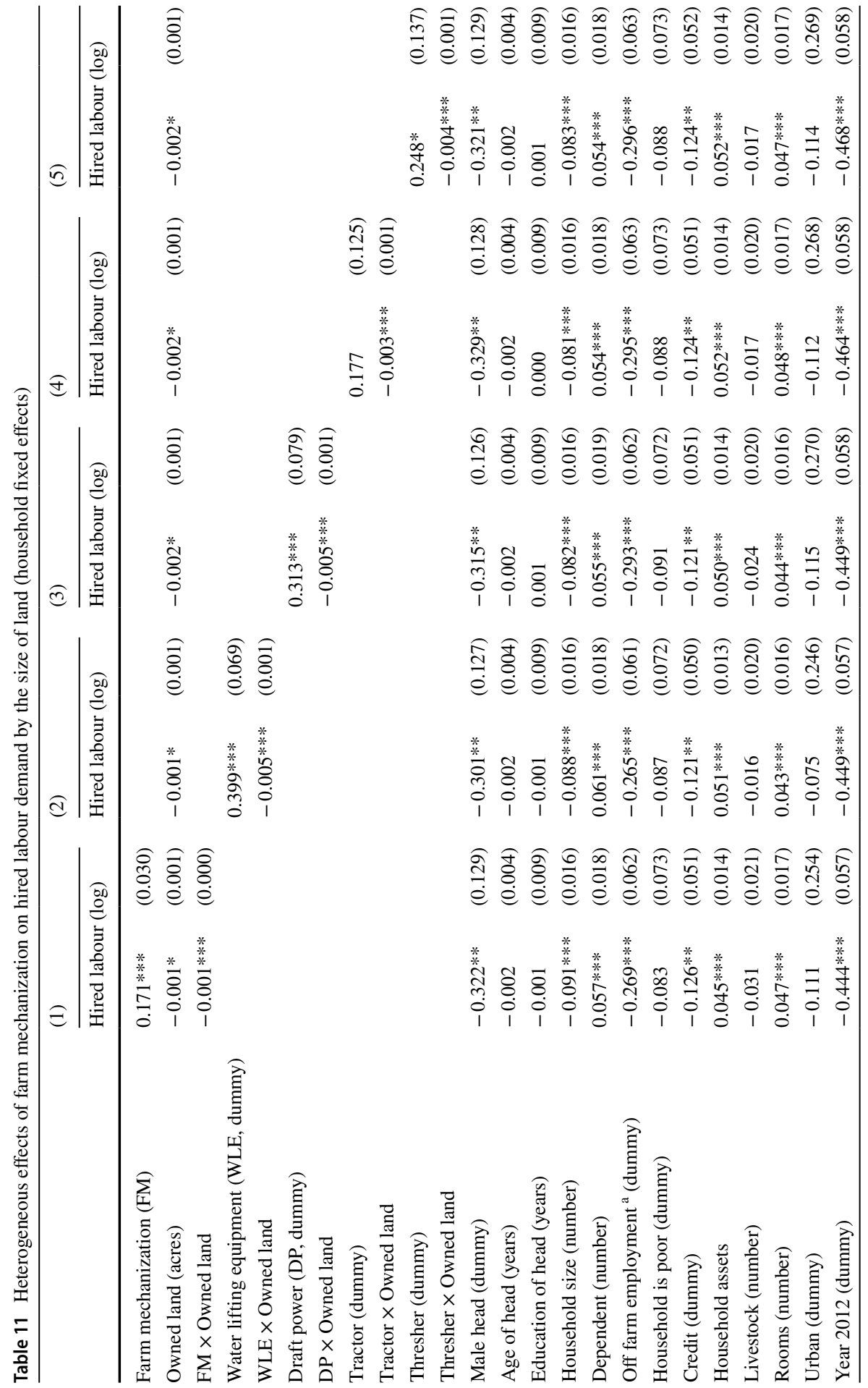




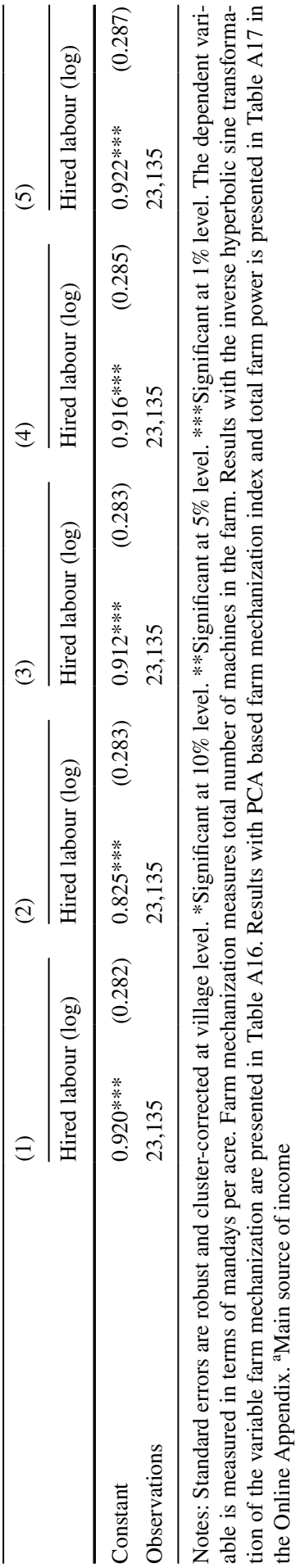


Furthermore, Table A18 to Table A20 in the Online Appendix present the heterogeneous effects of farm mechanization on household farm labour participation by farm size. In Table A18, Table A19 and Table A20, we present the results for household adult male members, adult female members and children, respectively. In Table A18 column (4), the interaction term between ownership of tractors and size of the owned land is statistically significant and positive, thus suggesting that for male adult members, as the size of land increases, the effect of tractors on the probability of male household member's farm labour participation increases. This is again pointing to expected changes in the types of farm activities that male household members engage in, mainly toward more control or management activities with increased use of mechanization; even though we do not have enough data to support this claim in detail. We also find in column (4) in Table A20 in the Online Appendix, a significant and negative effect of the interaction term between tractor ownership and land size for the disaggregated analysis for children. Thus, indicating that the effect of tractor ownership on the probability of child participation in farm activities decreases with farm size. However, for adult female members (Table A19 in the Online Appendix), we do not find a statistically significant effect on interaction terms between the various measures of farm mechanization and land size.

\section{Conclusion}

Population growth and urbanization have increased the need for sustainable agriculture intensification to meet the growing food demand. Intensification of agricultural systems is usually associated with increased labour requirements along with other input requirements per unit of cultivated land. However, better employment opportunities in the non-farm sector have resulted in severe labour shortages during the peak agricultural season and have increased rural wages in many developing and emerging economies. The theory of induced innovation suggests that increasing wages and labour scarcities cause a substitution of labour for mechanical power or labour-saving technologies, but extensive use of labour-saving technologies may cause labour displacement and have serious equity concerns. In this paper we analyse the association between the level of farm mechanization as well as the relationship between different types of farm machines such as water-lifting equipment, draft power, tractors and threshers on hired and family labour requirement. We use nationally representative panel data from India and apply household and individual fixed effect estimation approach. We also analyse the consequences of farm mechanisation on the expansion of farmland and intensification of input use to better understand the mechanism of effect on farm labour requirement. Finally, the study examines the heterogeneous effects of farm mechanisation based on the size of cultivable land.

The results suggest that a unit increase in the level of farm mechanization increases the demand for hired farm labour by $12 \%$. Moreover, we find that the level of farm mechanization increases the probability of men and women working on their farms, while it decreases the probability of children participating in farm-related work. Disaggregated analysis based on types of farm machinery suggests that waterlifting equipment, draft power and tractors increase the probability of adult male 
members working in their farms, while all types of farm machines, except tractors, have a positive effect on the likelihood of female farm labour participation. The analysis of heterogeneous effects suggests that irrespective of the type of farm machinery, the effect of farm mechanization on the demand for hired labour decreases as the size of the farm increases. Furthermore, as the size of land increases, the effect of tractors on the probability of male household member's farm labour participation increases and the probability of household child labour decreases.

Before we conclude, we acknowledge three limitations of this study. First, due to the limitation of the data, we have analysed the effect of farm mechanization on overall labour requirement and not by farming activities. Second, the IHDS dataset had information only on ownership of farm machinery and not farm rental services and, therefore, our measure of farm mechanization does not include farm rental services. However, during the period of the survey, rental services for farm machines were in their nascent phase and only in select regions of the country. Thus, we do not expect our results to be strongly affected by it. Third, although we have used a panel data fixed effect estimator to control for time-invariant unobserved factors, the estimation is unable to address potential endogeneity arising from time-variant factors or biases dues to reverse causality. Irrespective of that, the results remain informative about mechanisms through which mechanization can influence labour demand. Follow-up research in other countries and regions should consider analysing the effects of farm mechanization on the labour requirement of different farming activities and also incorporate the farm rental services into their analysis.

Supplementary Information The online version contains supplementary material available at https://doi. org/10.1007/s41775-021-00120-x.

Funding Open Access funding enabled and organized by Projekt DEAL. The authors did not receive support from any organization for the submitted work.

Availability of data and materials Data are available on request.

\section{Declarations}

Conflict of interest On behalf of all authors, the corresponding author states that there is no conflict of interest.

Ethics approval Publicly available data were used for the analysis.

Open Access This article is licensed under a Creative Commons Attribution 4.0 International License, which permits use, sharing, adaptation, distribution and reproduction in any medium or format, as long as you give appropriate credit to the original author(s) and the source, provide a link to the Creative Commons licence, and indicate if changes were made. The images or other third party material in this article are included in the article's Creative Commons licence, unless indicated otherwise in a credit line to the material. If material is not included in the article's Creative Commons licence and your intended use is not permitted by statutory regulation or exceeds the permitted use, you will need to obtain permission directly from the copyright holder. To view a copy of this licence, visit http://creativecommons.org/licen ses/by/4.0/. 


\section{References}

Afridi, F., Bishnu, M., \& Mahajan, K. (2020). Gendering Technological Change: Evidence from Agricultural Mechanization. In IZA Discussion Paper (No. 13712). www.iza.org. Accessed on 13 April 2021.

Benin, S. (2015). Impact of Ghana's agricultural mechanization services center program. Agricultural Economics, 46(S1), 103-117. https://doi.org/10.1111/agec.12201

Binswanger, H. P., \& Pingali, P. (1984). The evolution of farming systems and agricultural technology in Sub-Saharan Africa. Agriculture and Rural Development Department. World Bank. Report no: ARU: 58.

Binswanger, H. P., \& Ruttan, V. W. (1978). Induced innovation: Technology, institutions, and development. Johns Hopkins University Press.

Boserup, E. (1965). The conditions of agricultural growth. The Economics of Agrarian Change under Population Pressure.

Cameron, A. C., \& Trivedi, P. K. (2005). Microeconometrics: Methods and applications. Cambridge University Press.

Caunedo, J., \& Kala, N. (2021). Mechanizing agriculture. National Bureau of Economic Research Working Paper Series. https://doi.org/10.3386/W29061

Daum, T., \& Birner, R. (2020). Agricultural mechanization in Africa: Myths, realities and an emerging research agenda. Global Food Security, 26, 100393. https://doi.org/10.1016/j.gfs.2020.100393

Desai, S., Vanneman, R., \& National Council of Applied Economic Research, N. D. (2019). India Human Development Survey Panel (IHDS, IHDS-II), 2005, 2011-2012. Inter-university Consortium for Political and Social Research [distributor]. https://doi.org/10.3886/ICPSR37382.v1

Hayami, Y., \& Ruttan, V. W. (1970). Factor prices and technical change in agricultural development: The United States and Japan, 1880-1960. Journal of Political Economy, 78(5), 1115-1141. https://doi. org/10.1086/259694

Malabo Montpellier Panel. (2018). Mechanized: Transforming Africa's agriculture value chains. http:// ebrary.ifpri.org/cdm/ref/collection/p15738coll2/id/132766. Accessed on 25 Dec 2020.

Mrema, G., Baker, D., \& Kahan, D. (2008). Agricultural Mechanization in Sub-Saharan Africa: Time for a New Look. Agricultural Management, Marketing and Finance Occasional Paper, 22 (FAO).

Pingali, P. (1997). From subsistence to commercial production systems: The transformation of Asian agriculture. American Journal of Agricultural Economics, 79(2), 628-634. https://doi.org/10.2307/ 1244162

Pingali, P. (2007). Chapter 54 Agricultural mechanization: Adoption patterns and economic impact. In R. Evenson \& P. B. T.-H. of A. E. Pingali (Eds.), Agricultural development: Farmers, farm production and farm markets (Vol. 3, pp. 2779-2805). Elsevier. https://doi.org/10.1016/S1574-0072(06) 03054-4

Pingali, P., Yves, B., \& Binswanger, H. P. (1988). Agricultural mechanization and the evolution of farming systems in sub-saharan Africa. Johns Hopkins University Press for the World Bank, 1987.

Ruttan, V. W. (2002). Productivity growth in world agriculture: Sources and constraints. Journal of Economic Perspectives, 16(4), 161-184. https://doi.org/10.1257/089533002320951028

Ruttan, V. W., \& Hayami, Y. (1984). Toward a theory of induced institutional innovation. The Journal of Development Studies. https://doi.org/10.1080/00220388408421914

Singh, S., Singh, S.R, \& Singh, S.P. (2014). Farm power availability on Indian farms. Agricultural Engineering Today, 38(4), 44-52. https://www.indianjournals.com/ijor.aspx?target=ijor:aet\&volume= $38 \&$ issue $=4 \&$ article $=008$. Accessed 10 Nov 2020 .

Wang, X., Yamauchi, F., \& Huang, J. (2016). Rising wages, mechanization, and the substitution between capital and labor: Evidence from small scale farm system in China. Agricultural Economics, 47(3), 309-317. https://doi.org/10.1111/agec.12231

Publisher's Note Springer Nature remains neutral with regard to jurisdictional claims in published maps and institutional affiliations. 